\title{
Following the turkey tails: neoliberal globalization and the political ecology of health
}

\author{
Merrill Singer ${ }^{1}$ \\ University of Connecticut, USA
}

\begin{abstract}
The objective of neoliberal globalization, as noted by various observers, is not the improvement of global health and wellbeing but the expansion of deregulated markets in international trade and investment, a characteristic affirmed and illustrated in this article through an examination of the global commoditization of turkey tails and the role of world trade institutions and policies in this process. The article, a contribution to the political ecology of health, assesses the deleterious factors that stem from trade in this fatty commodity as it flows from poultry farms in the U.S. into the indigenized diets and changing bodies of people in several developing nations in the Pacific, Ghana, and beyond.
\end{abstract}

Key words: Neoliberal trade, global food commodities, food culture, political ecology of health, Pacific islands.

\section{Résumé}

L'objectif de la mondialisation néolibérale, comme indiqué par divers observateurs, n'est pas l'amélioration de la santé mondiale et le bien-être, mais l'expansion des marchés déréglementés dans le commerce international et l'investissement, une caractéristique affirmé et illustré dans cet article à travers l'examen de la marchandisation mondiale de la queue de dinde et le rôle des institutions et des politiques commerciales mondiales dans ce processus. L'article, une contribution à l'écologie politique de la santé, évalue les facteurs délétères qui découlent de commerce de ce produit gras comme il coule des fermes de volaille aux États-Unis dans les régimes indigénisés et l'évolution des corps de personnes dans plusieurs pays en développement dans le Pacifique, Ghana, et au-delà.

Mots clés: commerce néolibérale, les produits alimentaires mondiaux, la culture de la nourriture, de l'écologie politique de la santé, les îles du Pacifique.

\section{Resumen}

Como ya han comentado otros investigadores, el objetivo de la globalización neoliberal no es el de mejorar la salud global y el bienestar, sino la expansión de los mercados no regulados en el comercio e inversiones internacionales, una característica que se reafirma e ilustra en este artículo a través de un examen detenido de la comodificación global de las colas de pavo y el papel que juegan las instituciones mundiales de comercio y las políticas que se siguen en este proceso. Este artículo, entendido como una contribución a la ecología política de la salud, evalúa los efectos dañinos que surgen del comercio relacionado con este grasoso producto y la manera en que se mueve desde fincas en los Estados Unidos a las dietas nativas y produce un cambio en los cuerpos de la gente en varias naciones en vías de desarrollo en el Pacífico, Ghana y otros más.

Palabras clave: comercio neoliberal, productos alimentarios globales, la cultura alimentaria, la ecología política de la salud, las islas del Pacífico.

\footnotetext{
${ }_{1}$ Merrill Singer, Professor, Department of Anthropology and Department of Community Medicine, University of Connecticut, Storrs, CT 06269, USA. Email: merrill.singer "at" uconn.edu. The author thanks reviewers, and G. Derrick Hodge for his close reading, discussion, and comments on an earlier draft of this article.
} 


\section{Introduction}

Globalization has been described as the "creation of new economic, financial, political, cultural and personal relationships through which societies and nations come into closer and novel type of contact with one another" (Waters 2005:8). Such definitions suggest that "closeness" involves a kind of social leveling between nations. Yet analyses suggest that among the forces driving this worldwide transformation is the emergence of a global market, the movement of capital, rapidly evolving communication technologies, and a set of trade policies pushed by development and trade institutions that remove controls on capital movement and support a neoliberal free-flow of commodities across ever-more porous national boundaries (Haugerud et al. 2000). As a theory of trade economy and society, neoliberalism asserts that every country should produce what it is best at producing, and freely trade those goods with other countries. Unrestricted trade, it further posits, benefits all nations as the market sets appropriate prices and facilitates broad distribution. Whatever the accuracy of this depiction, one clear consequence of such commodity movement is the restructuring of social life in ways that have telltale health impacts. Specific health benefits of globalization have been noted, such as the greater availability of medicines in developing countries, and the prevailing belief is that global trade has a generally positive impact on health (Dollar 2001; Feachem 2001). But many global health analysts conclude that on balance, globalization further advances health inequalities, for poor nations in particular (Singer and Erickson 2013).

The central objective of neoliberal globalization, as McMichael and Beaglehole (2000) and others observe, is not improving health but the expansion of deregulated markets in international trade and investment, a characteristic affirmed and illustrated in this article through an examination of the global commoditization of turkey tails and the role of world trade institutions in this process. In this article I assess the health factors that stem from trade in this commodity-with consideration of mutton flaps as a parallel example-as it flows from poultry farms in the U.S. into the diets of people in several developing nations, based on a synthesis of relevant literatures on turkey production, export and import of unhealthy foods, indigenization of invasive diets, and local consumption patterns. I trace the transnational trail that leads from raising turkeys to raising rates of chronic diseases, using an anthropology of socialized commodities approach that incorporates an assessment of neoliberal globalization, cross-cultural encounter, large-scale economic transformation, informal economy, and culturally influenced consumption and consumer culture in local social environments (Appadurai 1986; Foster 2006; Miller 1995). Such analysis across scales and locations contributes to our understanding of the political ecology of health in a globalizing world (Baer and Singer 2009; King 2010).

\section{Toward a social life of turkey tails}

As Appadurai (1986) has argued, economic exchange creates value, and commodities are objects of economic value. Turkey tails refer to the meat and gristle around the pygostyle ("rump pillar" or "parson's nose"), and they are a fleshy byproduct of food production with limited value in the U.S. (Figure 1). They have been transformed into a commodity with economic value in international trade. Like other commodities, it can be argued that turkey tails "like persons, have social lives" (Appadurai 1986:3) and they have meaning endowed by their interaction with humans. To understand the social life of commodities, their attributions, and their inscribed meanings, "we have to follow the things themselves" as they circulate along a trajectory of human transactions (Appaduari 1986:5). As this suggests, commodities are thoroughly socialized things-inmovement, that are consumed in some fashion. In the case of turkey tails, a global trajectory of exchange:

(1) begins on poultry farms that produce turkeys, and with the social meanings inscribed in their "tails" by direct producers;

(2) at slaughter, tails are severed mechanically from other culturally conceived "parts" or cuts of what were once living birds;

(3) these are packaged, frozen, and shipped internationally through various hands and with varying cultural understandings...

(4) ...to arrive at a retail outlet at a relative small number of places in the world; 
(5) where they are displayed and acquired by consumers or producers and sellers of prepared foods; and,

(6) ultimately consumed by people whose possess their own sets of meanings and words about what for them may have become a desired food item, a cultural assemblage that includes knowledge about how to prepare it, when and where to eat it, and what its eating communicates in social contexts. Cultural frames are not shared with the original producers.

This trail is followed in the article. While Apparadui suggests that things can move in and out of a commodity state, in the case of turkey tails, from the viewpoint of the farmer, they begin as candidate commodities (since sales drive turkey production), they travel across national boundaries as frozen containerized commodities, and are acquired in raw or prepared form by consumers. The latter value them not for their exchange value (although their price is critical) but for their use value as an inexpensive, tasty, and culturally meaningful food. In both their commodity and noncommodity phases, turkey tails are objects of communication that carry cultural messages between people.
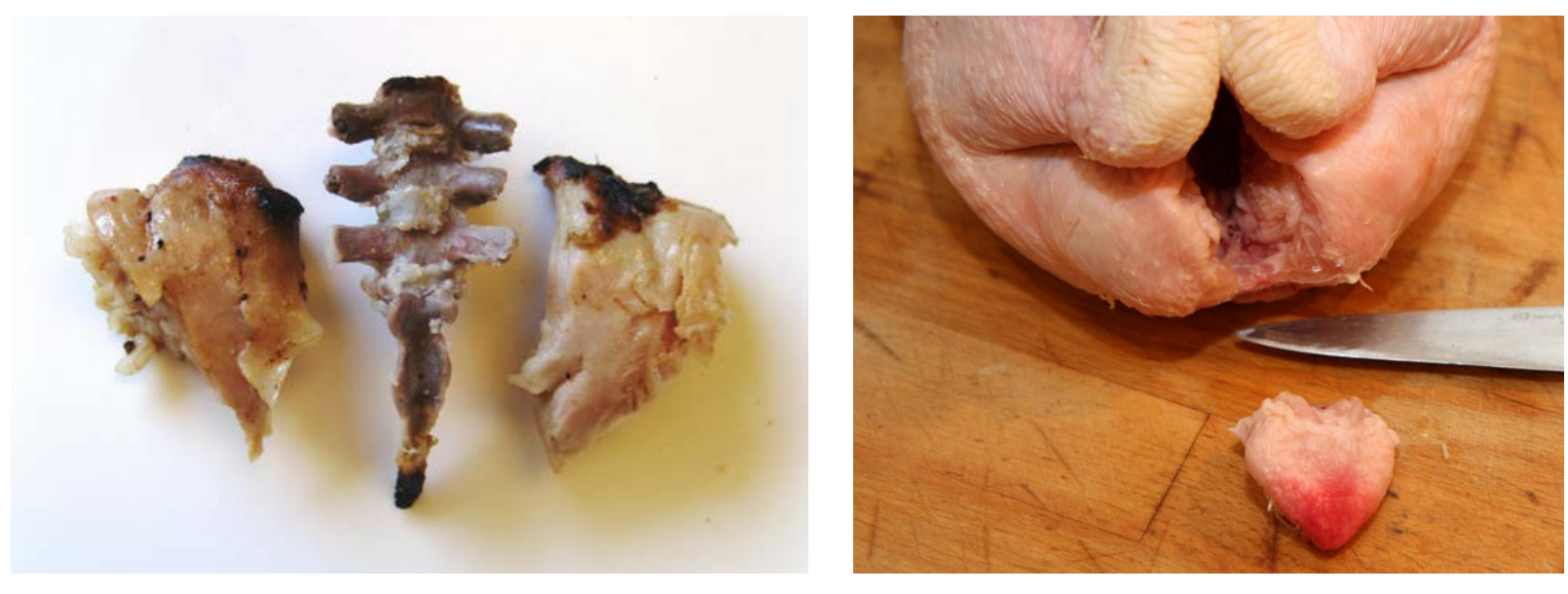

Figure 1. Turkey tails. Sources: http://tinyurl.com/mpw2fjn and http://www.cookipedia.co.uk

Humble turkey tails, in short, are quintessential commodities. Their life histories are dominated by their social life as objects of exchange, but their biographies are not exhausted by this phase, which would not exist without its final noncommodity closure as a desired thing in the world. In this final phase, the turkey tail commodity is transformed within the contexts of societies, languages, and cuisines that have no traditional direct knowledge of or exposure to turkeys as living birds. Rather, turkey tails have been absorbed into, and given novel cultural meanings, as a consequence of international patterns of trade between developed and developing nations. As Kopytoff (1986:67) observes, what is significant about the adoption of alien objects like turkey tails "is not the fact that they are adopted, but the way they are culturally redefined and put to use" by different social groups. A parallel is the pivotal cultural role of codfish—a cold water fish that cannot live in the Caribbean-in the desired cultural dish of bacalao within contemporary Caribbean cuisines, or the alternative bakalar s krumpirom, a popular codfish and potato dish among Serbians and Croatians, or the French brandade, a codfish dip, the turkey tail and its consumption embody the political ecology of a globalized world. Analysis of mobile commodities like turkey challenges the dominant understanding that neoliberal globalization is inevitable and homogenizing, revealing it instead to be "partial, uneven and unstable; a socially contested rather than logical process [giving rise to] many spaces of resistance, alternity and possibility" (Whatmore and Thorne 1997:289). 


\section{Restructuring of the turkey industry}

The cultural biography of turkey tails begins with the raising of turkeys as a source of food-based profit. These entwined use and exchange values rest on an underlying conceptual and emotional frame in which turkeys play a role in the U.S. cultural imaginary, linked to the national Thanksgiving holiday and to a set of historically rich ideas and images of the raising of small flocks of free range birds by yeoman family farmers. Benjamin Franklin (1907), in fact, bemoaned the selection of the bald eagle as the national bird, feeling the turkey to be "...a much more respectable Bird, and withal a true original Native of America."

By time of the Civil War, Franklin got his wish as the Thanksgiving turkey came to be elevated to a symbol of national productivity and abundance that was deeply embedded in American cultural life. By contrast, geese, which came with European settlers to the New World and which had a traditional cultural attachment in Europe to Christmas feasting, failed to win a significant place in the American cuisine and the number of domestic geese declined over time. ${ }^{2}$ As a result, unlike turkeys, geese remain one of the few meatbirds in the U.S. that are not mass-produced on factory farms (except those raised to produce foie gras) and several wild goose breeds in the U.S. are endangered. Turkeys, by contrast, are produced commercially in prodigious numbers and their wild cousins have recovered from a drastic decline to inhabit all states except Alaska.

With reference to the social importance of Thanksgiving, as Siskin (1992:167) observes, through such traditions "nations are imagined." Further, this symboling is entrenched in a nationalist religious ideology:

The belief that God has especially favored this land is deeply embedded in Thanksgiving. We act it out within the Thanksgiving meal as we give thanks to the Lord for all his blessings. The blessings are manifested in the food itself: its quantity, its voluminousness. We eat until we can eat no more (Santino 1994).

The advertising industry promotes images of turkeys, pumpkins, and cornucopias associated with Thanksgiving by linking them in their sales pitches to emotionally charged notions of bounty, prosperity, and abundance. By the late 19th century, civic, religious, and folk liturgies were intertwined with commercial holiday rituals that centered on social consumption (Pope 1997). The centrality of turkey to the Thanksgiving event is expressed in direct popular reference to the holiday as "turkey day." At a deeper level, beneath the subtle and more overt expressions of reaffirmed cultural and social unity associated with the invented tradition of Thanksgiving, the stuffed turkey might be read as representing "Native Americans, sacrificed and consumed in order to bring civilization to the New World" (Siskin 1992:168). In other words, rooted in American turkey symbolism is a set of ideas about the ethnic Other that provides a cultural context for the unquestioned shipping of fatty and unhealthy turkey tails for consumption by distant Others in developing nations.

In 1989, a new cultural wrinkle was added to the tale of the turkey in American society: the formal presentation of a live Thanksgiving bird to the President of the United States, usually by the National Turkey Federation and the Poultry and Egg National Board, and the presidential pardoning of the bird to live out its days on display at the Mount Vernon estate of George Washington. ${ }^{3}$ Adding to the entwinement of cultural symbols, from 2005 to 2009, before retiring these birds were flown to Disneyworld to serve on a decorative float, along with a waving Mickey Mouse in colonial dress, as the grand marshal of the Disneyworld Thanksgiving Day Parade. Birds that play this nationally televised role are not selected randomly from farm stock; rather they are hand-picked at birth and trained to remain calm in the presence of many people, loud noises, and flash photography. Because focused breeding for desired characteristics and growth hormones have led to a significant physical restructuring of turkeys (e.g., anatomical manipulation has left them unable to reproduce naturally with internal organs unable to support their body size), these celebrity birds do not, contrary to what is reported by the National Turkey Federation (2012) on its website, leave Washington to

\footnotetext{
2 Modern turkeys had already been taken to Europe from North American wild flocks.

3 A practice subsequently limited to a one month stay before transfer to Morven Park in Virginia, because the Mount Vernon Ladies' Association of the Union Board of Regents decided that the birds violated the estate's policy of maintaining "historic accuracy" - but possibly influenced by the delicate condition of pardoned birds.
} 
rest comfortably in their new home. Rather, they soon develop heart, respiratory, and other health problems and usually are dead within a year of their televised public debut (Hall 2012). Thus there is no press coverage at Thanksgiving of the previous beneficiaries of presidential pardon strolling in peaceful comfort at Morven Park.

The condition of presidentially pardoned turkeys reflects a far-reaching restructuring of the U.S. turkey industry over the last hundred years. Like most other sectors of agriculture in the country, the turkey industry has become increasingly concentrated and vertically integrated. In the past processors owned turkey flocks and their feed, and farmers raised the birds for a set fee. Today processors own and manage most turkey operations. In 1929 there were 600,000 turkey farmers with an average of 26 turkey per farm; seventy years later there were only 6,000 turkey farmers producing 51,000 turkey per farm (Hart 2003). In Minnesota, the largest turkey producing and processing state in the U.S., only 250 farmers produce over 45 million turkeys a year (Minnesota Turkey 2014).

An increase in technology and mastery of turkey breeding have led to highly specialized operations. Each part of the production process now requires a specialized site, beginning with laying facilities and ending in slaughter houses. In the middle are the factory farms where birds are raised (after parts of their toes and upper beaks are removed to reduce pecking and scratching) for six months in dimly lit sheds with limited space for individual movement (about 3.5 feet $^{2}$ or $0.32 \mathrm{~m}^{2}$ per bird). This process produces about 25 million turkeys per month (National Agricultural Statistics Service 2007). Industrial turkey farms have become the norm, with 80 percent employing more than 400 people (Ollinger et al. 2001). Giant agribusiness processors largely control the industry. The result is that, as has been noted for tobacco farmers (Benson 2012), turkey farmers function at the mercy of large operations, detaching the entire industry from traditional family farming patterns. Together, the Big Three corporations processed 3.75 billion pounds (1.7 billion $\mathrm{kg}$ ) of turkey in 2009. Restructuring of the sector is guided by the underlying logic of capital accumulation, leading to an increasing concentration of wealth and ever widening disparities within and across nations.

Concomitant with growth, vertical integration, and concentration of wealth have been various slaughtering innovations and faster plant line speeds, as well as the development of an array of new turkey products designed for the "busy lifestyle" of modern consumers (Minnesota Turkey 2014). Aggressive and increasingly sophisticated marketing contributed to a tripling in national consumption of turkey in the U.S. between 1975 and 1999, achieving an annual per capita consumption level of eighteen pounds (18 kg) by 1999 (Daykin 2001). Increases in consumption levels have been facilitated by the rising level of meat processing in the turkey industry (Ollinger et al. 2001). This has enabled the industry to expand its market beyond the winter holiday season and, increasingly, beyond the U.S. market. As Americans tend to avoid turkey tails, seeing them as unhealthy parts of the bird or not even as food, they often are not included in packaged birds or plastic wrapped grocery store cuts; consequently, there are many millions of turkey tails available for sale on the international market (Lubin 2010).

\section{Going global}

As in other industries under neoliberal globalization, there is a constant need to expand markets, and thus a drive to develop international markets for turkey products. The U.S. is the leading exporter of this commodity, estimated to amount to 336,000 tons (341,392 tonnes) in 2012. However, forecasts suggest no significant increases in U.S. sales in coming years, and there was a drop in exports and consumption in 2013 (The Meat Site 2013). Indeed, the hunt for new international markets, combined with the need to profit from all parts of processed turkeys, has driven the creation of markets for tails in Micronesia, Samoa, Ghana and elsewhere. In 2008, over ten thousand pounds $(4,535 \mathrm{~kg}$ ) of turkey tails were exported to these markets (U.S Department of Agriculture 2008). The dumping of a fatty food on poor countries is sometimes couched as "foreign aid." Referring to aid from New Zealand and the export of mutton flaps ${ }^{4}$ to Tonga, the Tongan Prime Minister, Prince Ulukalala Lavaka Ata (2002) aptly commented, "We should not be under any illusion that they do this for our own good."

\footnotetext{
${ }^{4}$ Sheep bellies—a very fatty cheap offcut of sheep or lamb rib meat.
} 
This assessment is supported by analyses of humanitarian food-aid programs ostensibly intended to provide food for those in need. The U.S. is the largest food aid donor globally but it has emphasized aid policies that appear self-interested, rather than primarily targeted to helping people facing dietary challenges. As Oxfam International reports:

The US food aid system creates opportunities for a variety of private interests to skim off benefits in the procurement, packaging, transportation, and distribution of commodities.... For example, the US government requests bids for sales of surplus agricultural commodities from a limited list of pre-qualified US-based agribusiness companies, and arranges the transportation of these commodities from the USA to recipient countries on US-flagged ships. The bidding process results in purchase and transportation expenses that are substantially higher than market costs (Krispe 2005:12-13).

This pattern of commodity dumping is seen, for example, in the efforts of U.S. rice producers in the closing years of the $20^{\text {th }}$ century and early years of the $21^{\text {st }}$ to cope with stagnating domestic production and inadequate importation by other countries to profitably dispose of rising production yields, by relying on government assistance in the form of food aid programs that became ever-greater buyers of surplus rice. Influential food commodity groups have learned to pressure food aid programs to serve as an export safetyvalve for surpluses (Law 2001).

Yet James Sumner, president of the U.S. Poultry and Egg Exporting Council, a trade association dedicated to increasing exports of U.S. poultry and eggs worldwide, maintains that the shipment of turkey tails to countries like Samoa "was obviously as a result of Samoan demand, not the attempt of the U.S. industry to force other countries to take our turkey tail products... We're not out trying to develop markets around the world for duck tongue, turkey tails or chicken feet" (Barclay 2013). Sumner stressed that "it's the consumers' right to determine what foods they wish to consume" (International Economic Law and Policy Blog 2011). While markets for duck tongues have not (yet) been developed, those for turkey tails and chicken feet, along with wing tips, necks, frames, and other poultry byproducts, certainly have. And Sumner is surely aware that by 2009 the U.S. was shipping 377,805 metric tonnes of chick paws (as chicken feet are known in the industry) to China with a net value of US\$278 million (Richburg 2011). Notably, while better cuts of turkey are graded by quality, there are no grade standards for turkey tails (U.S. Department of Agriculture 1995). Like poultry necks, wing tips, giblets, and diced or shredded turkey meat, tails apparently are not seen as being capable of having inherently premium qualities by the U.S. Department of Agriculture.

On the import end of the turkey tail trade, several factors serve as important drivers of consumer demand, including growth of the cash economy, population increase, urbanization, and resulting changes in work and leisure patterns. Also of importance are shifts in government policies. Traditional diets of Pacific island populations, for example, were based on root crops and starchy fruits, seafood, leafy greens, and various fruits and nuts. The entry of turkey tails into the diets of poor countries in the Pacific and elsewhere was inaugurated as other imported canned meats and carbohydrates began to penetrate and restructure communities' eating patterns. In Samoa, meat byproducts such as canned Spam, corned beef, and mutton flaps, were introduced for consumption sometime after World War II, and turkey tails came shortly thereafter (Barclay 2013). In Micronesia, Marshall (2004) notes that turkey tails have been part of local cuisine in the island nation of Chuuk for almost two generations.

Facilitating the movement of cheap foodstuffs into low income countries has been government liberalization of trade policies which has "opened these countries to cheap, fatty meat imports" (Thow et al. 2011: 35). This is, of course, the intended outcome of "free" trade regimes that force countries - via the World Bank, International Monetary Fund, and World Trade Organization - to accept whatever products will profit the already wealthy countries. Thus, by 2002, the 22 island nations that comprise the Pacific Island Countries and Territories received US\$30 million in cheap, low quality meat cuts from wealthier nations (Wyber, Wilson and Baker 2009).

This pattern has repeated itself more recently in the former Soviet Republics. After liberalizing its trade policies as part of accession to the World Trade Organization, including cancelation of a $13 \%$ import 
duty on meat products, in 2008 Ukraine was suddenly swamped with imported low quality meats, such as turkey tails. According to Alexander Bakumenko, Chairman of the Board of Directors of the Ukrainian Poultry Producers Union:

Nowadays large amounts of low-quality, and sometimes expired poultry production is imported to the country... The majority of the imported goods is low-quality raw materials: food byproducts, skeletons, meat of mechanical boning, scraps, fat, tails and so on (USA Poultry and Egg Export Council 2009).

The Union of Poultry Producers of Kazakhstan reports that a jump in the import of low-quality, cheap poultry products from U.S., other former Soviet Republics, and other countries, has left the local poultry producers on the verge of bankruptcy (USA Poultry and Egg Export Council 2013).

Beyond the appeal of their comparatively cheap prices, Hughes and Lawrence (2005:299) found that the "acceptance and/or belief that foreign goods and services are superior" to local products has led to "consumption of [imported] foods of low nutritional quality" in many developing nations. This behavior, a feature of a globalized modernity, has found expression in numerous commodity arenas. Will Straw (1998), for example, a Canadian who has written about oppositional music genres, like punk rock or gansta rap, notes that the early vinyl recordings of these rebellious musical forms gained considerable worth in the eyes of enthusiastic Canadian consumers because of their origin in Britain or the U.S. Having been transported from the centers of alternative culture and power, the records, as physical things, acquired an aura, the "principal effect [being] to render them cherished and precious." Similarly, a Tajik youth who became addicted to heroin stated to journalists, "It was very prestigious, we saw drugs in movies" (quoted in Shishkin and Crawford 2006). To this youth, like many others in developing countries who have become addicted to opioids, this illicit commodity represented a valued point of contact with the mystified West, a glittery place, filled with fancy cars, enormous homes, a diverse array of electronic gadgets, plentiful food, and, perhaps most important of all, glamour and esteem. According to Wendy Snowdon, co-coordinator of the Pacific Research Centre for the Prevention of Obesity and Non-communicable Diseases, "Colonialisation of the Pacific brought a lot of these ... foods in, with the perception that because they were imported they must be better. Habits started to develop around high-fat, -salt and -sugar items" (Seccombe 2012). Underlying such habits was a kind of fetishism, the belief that commodities possess an intrinsic value and are "endowed with a life of their own" reflective of social relations (Marx 1990:165).

In their mutton flap research, Gewertz and Errington (2007) interviewed meat traders in New Zealand and Australia, most with extensive experience in overseas sales, including shipment to Pacific islands. They reported that for Pacific Islanders, animal protein historically was scarce and culturally constructed as a highly valued luxury item. As a result, imported meat products, even very low quality cuts, were viewed as desirable - something European explorers, whalers and missionaries quickly discovered and sought to use for their own economic advantage. In this sense, from the perspective of the traders, Pacific island populations were a global entrepreneur's dream that promised handsome profits even from the sale of low-quality and low-margin products. Exporters seized this opportunity to cultivate local markets for cuts that were undesirable in their country of origin. In the case of turkey tails, the availability of this product was probably facilitated by the diversification of the market in the U.S. for turkey breasts, thighs, and sliced deli meat, preferences that did not include tails. Thus, tons of tails represented a plentiful commodity awaiting a consumer, one that was "discovered" by meat exporters with an eye for marketing novel products, in the name of profit, to those who had not previous expressed any desire for them. These traders in cheap foodstuffs, Gewertz and Errington (2007: 501) found, do not tend to have moral qualms about the health impacts of their products: "As long as the meat is properly processed from healthy animals, kept frozen along the way, and is what was ordered, a trader's responsibility has been fulfilled."

In this same way, turkey tails joined the ranks of other imported foodstuffs adopted into the diet in various countries of the Pacific, Ghana, and beyond. Beyond a mere addition to traditional diets, however, imported "white rice, flour, sweet and refined foods, and fatty meats have increasingly replaced local foods" (Englberger, Marks and Fitzgerald 2002:5). In this way, they have had the impact of an invasive species that 
pushes out indigenous organisms and disrupts bioregions. Increasingly, especially in the period since World War II, relatively health indigenous diets have disappeared in many countries, imported foods have become dominant, and nutrition-related disorders "have become serious problems and appear to be the consequence of dietary and lifestyle changes" (Englberger, Marks and Fitzgerald 2002:5).

Yet, in many locales, as traditional foods became more costly relative to imports, less available, and were seen as taking longer to prepare than imported food sources, introduced foods came to be seen and experienced not as foreign goods but as familiar and emotionally charged constituents of the (emergent) local cuisine by assuming the role of what have come to be called "comfort foods." There is a certain irony here in that comfort foods, those pregnant with deep sentimental attachments, have been analyzed as a type of selfmedicating response to emotional stress of changing lifestyles and as a key contributor to the global epidemic of obesity (Dallman et al. 2005). In Ghana, for example, which became a market for 1400 metric tons of poultry from the U.S., mostly turkey tails (Crawford et al. 2010), they locally were dubbed Chofi (alternately spelled tsofi), and achieved status as an indigenized component in a desired local meal, as noted by Ghanaian journalist Ato Kwamena Dadzie (2010):

'Chofi' is the best accompaniment, with 'shitor' [a tomato and fish-based hot sauce], for fried yams. It's cheap. It's filling. And it's good to share. Almost every Ghanaian has enjoyed 'chofi' at one point or another. Yes, it's a national delicacy.

As one of the street foods available in Ghana, fried turkey tails joined the ranks of other items being hawked to cars by street vendors and sold at roadside fast-food stands. In this capacity, they entered into the informal economy and became a critical source of livelihood, primarily among women in the eastern regions of the country. As described by Nana Mansa, Chairperson of the Akuapem South Turkey Tail Traders Association in Ghana, chofi has allowed women involved in the local trade to pay for the education of their children and to afford their utility bills (Modern Ghana 2010).

Among some Pacific island communities, turkey tails similarly have won a place as a desired and familiar food item. In Samoa, they came to be called mulipipi. Notes Apaula Brown, a Samoan living in Washington, D.C.:

We usually boil the turkey tails first to get rid of the fat and then we chop the turkey tails into pieces... If we want to cook it in a chop suey, we mix it with vegetables; it's delicious (Barclay 2013).

Turkey tail were incorporated into the Samoan diet via various dishes, such as umu (barbeque), fried in soy sauce, or broiled in soup. In Hawai'i, tails are wrapped securely in taro leaves (luau) with fish and steamed to make a combo-dish called turkey tail laulau (leaf, leaf) that commonly is eaten with sweet potatoes or rice. In this recipe, turkey tail replaced the traditional use of pork and steaming replaced the use of an underground hot rock oven (imu). Sarah Munn (2010), who grew up on the Pacific island of Yap, describes the necessary ingredients of a Yapese party in her experience as follows:

Cases of cold Budweiser, bags of betelnut (with all the fixings), trays of multicoloured Calrose rice, and the thick, black smoke from turkey tails on the barbecue. These are the requirements for a good Yapese party.

In such contexts, the eating of turkey tails communicates sociality, group unity, relaxation, and feasting.

In Micronesia, turkey tails have even been incorporated into remittance items sent home by individuals who have found work in places like Guam, the largest island in Micronesia and an unincorporated territory of the U.S. As part of her examination of people from other Micronesian islands who migrated to Guam for work, Bautista asked her informants who came from Chuuk or other islands to report what if anything they sent or carried back home (on return trips) to relatives. They reported remitting cash, clothing, and food: 
The food items include ... chicken, turkey tails, and spare ribs, which are often carried in coolers, later filled with local foods upon return [to their home island]. On Guam, meat is often purchased in cases which is less expensive. A case of chicken parts or turkey tails cost about fifty cents per pound... (Bautista 2010:37).

In whatever form they are indigenized, the incorporation of turkey tails and parallel low quality foodstuffs into people's diets has been a key element in the transformation of local food cultures, a process that has significant health implications.

\section{Protecting public health and expanding profits}

Turkey tails certainly qualify as a fatty, unhealthy meat. Composed of the uropygial (the gland that produces oil for feather preening), surrounding lipid tissue, a small amount of meat protein, gristle, and skin, an average tail has a fat content of over $40 \%$; 15.69 grams of total fat, 4.595 grams of saturated fat, 53 miligrams of cholesterol, and 223 grams of sodium (Phys.org 2012). Saturated fats raise low-density lipoprotein cholesterol levels in human blood and contribute to cardiovascular and other health problems, including obesity. Regular consumption of turkey tails adds a significant amount of sodium to the diet and contributes to heightened blood pressure, which is also associated with obesity and heart disease.

As stressed at the WHO's sub-regional workshop on Trade, Trade Agreements and NonCommunicable Diseases held in February 2013, Pacific islanders have some of the highest rates of obesity and diabetes in the world. On Kosrae, one of the four districts in the Federated States of Micronesia, for example, Cassels (2006) reported that $88 \%$ of adults aged 20 or older were overweight (BMI $>25$ ), 59\% were obese (BMI > 30), and 24\% were extremely obese (BMI > 35). BMI (Body Mass Index), the ratio of the weight and the square of height, is an indicator of the nutritional status of a person. Similarly, diabetes has been identified as a health emergency in the populations of Pacific islands. A team of researchers led by Henry Ichiho has conducted a series of studies on non-communicable diseases throughout the Pacific. Among the highest rates of diabetes they identified was in American Samoa, where a population survey showed that $47.3 \%$ of adults had diabetes, while among individuals over 45 years of age this rate rose above $60 \%$ (Ichibho et al. 2013a). A calculation of mortality rates showed that diabetes was the second leading cause of death. These researchers found that $93.5 \%$ of study participants were overweight or obese.

A community household survey by this team on Palau, on the western edge of the Caroline archipelago, found that $22.4 \%$ of households reported a history of diabetes (Ichibho et al. 2013b). Ichibho and co-workers also reported the findings of a survey among Ministry of Health employees which showed that $44 \%$ of men and $47 \%$ the women were overweight and $46 \%$ of men and $42 \%$ of women were obese. On Majuro Atoll in the Republic of the Marshall Islands, these researchers found a diabetes prevalence rate of $19.6 \%$ with $42 \%$ of annual mortality being diabetes-related (Ichibho et al. 2013c).

As these data suggest, a pattern of high levels of obesity and diabetes, while varying in detail from island to island, are widespread among Pacific islanders. In Ghana, obesity does not tend to reach levels found in the Pacific, although in Greater Accra, Biritwum et al. (2005) found a rate of $16.1 \%$, with echelons of obesity going up with age. Moreover, those who reported taking insulin or blood sugar lowering medications were three times more likely to be obese or overweight compared to those who were not taking these medications, $16.0 \%$ vs. $5.5 \%$ respectively.

Increasing reliance on imported foods was identified at the Trade, Trade Agreements and NonCommunicable Diseases Workshop (2013) as having played a significant role in contributing to what was described as an "'epidemic' of obesity and related non-communicable diseases (NCDs)" in the Pacific region. Global food trade, more generally, has contributed to an international shift towards overweight and obese populations (Hawkes et al. 2010) and caused particular concerns in the Pacific (Brownell and Yach 2006; Curtis 2004). Thus, Shell (2001) has quipped "Spam and turkey tails have turned Micronesians into Macronesians." Dietary and related health shifts reveal one of the ways that advanced capitalist states - whose dietary norms are based far more on profitability than health - have exported "diseases of development" to poorer nations around the world. 
The term "nutrition transition" has been used to describe this shift toward unhealthy diets (Popkin 1998), including heightened levels of consumption of foods away from home, such as street foods and fast foods, settings in which prepared turkey tails commonly are eaten, and an inadequate consumption of fruits and vegetables. Two impacts of the global food trade in this regard were noted at the Workshop (2013:8): the development of unhealthy diets leading to NCDs and an undercutting of local agricultural production and increased imported food dependency. Changes induced by food globalization, in other words, are at once economic, cultural, social, and political ecological in nature.

Research indicates that dietary shifts - specifically, the adoption of diets that are high in fats (especially saturated fats and trans-fatty acids), free sugars, and salt, and low in fruits, vegetables, legumes, whole grains, and nuts - present significant risks for chronic diseases (Food and Agricultural Organization 2003). Along with declining levels of physical activity, changes in the food environment have been implicated in the global advent of chronic diseases, including direct and indirect impacts on obesity, diabetes, hypertension, high cholesterol, heart disease and cancer, and as a leading factor in global mortality. As a result of the nutrition transition, more people now die of heart disease in developing countries than in developed ones, and the problem has become particularly serious among the poor (World Health Organization 2004). So-called "lifestyle diseases" have produced "new ways of dying, to accompany the infectious diseases" of Pacific island and other lower income nations (Marshall 2004:55). Indeed, Marshall (2004:57) notes that the people of the island nation of Namoluk and other Micronesians have used the expression "turkey tail disease" to refer to chronic health conditions related to diet. Jackson (1997) has referred to this crisis as "dietary genocide."

Global trade in foodstuffs has been seen as triggering a westernization of diets (Pingali 2007). Turkey tails, as well as mutton flaps produced in Australia and New Zealand and primarily consumed in the Pacific Island nations of Tonga, Papua New Guinea, and Fiji—do not pay much if any role in western diets. Observe Gerwetz and Errington (2010:1) with reference to mutton flaps:

They move from First World pastures and pens in New Zealand and Australia, where white people rarely eat them, to Third World pots and plates in the Pacific Islands, where brown people frequently eat them-and in large numbers. As fatty and cheap meat, they are a kind of food implicated in the global epidemic of eating-related "lifestyle" diseases...

Indeed, Gerwetz and Errington note (2008:496), "those in NZ and Australia who produce [mutton flaps] often refuse to eat them." The issue, in other words, is not precisely the westernization of diets as much as it is incorporation, at the bottom, into a global food system in which valued, more expensive, and higher quality foods go to wealthier nations, and wealthier people in all nations, and poorer quality, cheaper, and riskier foods go to poorer nations and the poor people of all nations. There are, in short, convergent and divergent dietary outcomes produced by neoliberal globalization (Hawkes 2006). Further, notes Jackson (1997:89), "It is ridiculous that imported food is cheaper than local food, although not surprising as it is being dumped in Micronesia by western companies who can't sell it easily in their own countries." While Marx (1990) argued that social relations of production, and the sharp and consequential inequalities of labor across classes are masked by commodities, cases like turkey tail exports reveal how the availability and consumption of differing qualities of food unmask sharp and consequential inequalities across societies and social classes.

Although overall the pattern of cheap food marketing occurs in many countries, specific features vary, as neoliberal globalism produces, simultaneously, degrees of similarity and expressions of diversity. Turkey tails, thus far, only have found a market in some nations but not others. As Panapasa (2012) indicates "[t]urkey tail is marketed selectively to Pacific Island communities throughout the U.S. and in Pacific Island territories, as well as independent nations" and Ghana. The same is true of other meat byproducts and the broader catalogue of cheap, unhealthy exported foodstuffs, they are marketed to select locales. As this patterning suggests, factors such as the activities and connections of food exporters, the efforts of local food importers, and the development of historic cultural tastes in light of available options are important influences on the specific configuration of global cheap foodstuff distribution patterns. 
Recognition of the rising rates of overweight people and obesity, awareness of health risks associated with extra body fat, and growing understanding of the role of fatty meats and empty carbohydrates in the development of obesity, diabetes, and cardiovascular problems, ultimately triggered public health officials in a number of countries to advocate for import bans or restrictions on turkey tails. In 2007, the government of Samoa, at the request of the Prime Minister, formally banned the importation of turkey tails (unless they were attached to whole birds) to address the country's soaring rates of diet-related health problems. Palanitina Tupuimatagi Toelupe, chief executive officer of the Ministry of Health and a health educator, after developing a brief supporting the measure, announced the ban and indicated that other similar bans would follow (Radio New Zealand 2007). In 2008, at a meeting of the World Health Organization, the Samoan government asked for help in resisting the food marketing efforts of multinational food organizations. At the meeting, Stevenson Kuartei, Health Minister of Palau, supported the Samoa request explaining that traditional diets, which protected against diabetes and high blood pressure, were threatened by globalization and free trade. Fiji joined the ranks of Pacific island nations asking for help. As representatives of a turkey tail exporter nation, the U.S. delegates spoke against offering national assistance in blocking trade and argued instead that health education and prevention programs should be focused at the community or individual levels. Reflecting their entrenched neoliberal ideology, that sees consumption solely as a matter of means, desire and volition, the U.S. delegates lobbied to include a paragraph in the meeting's final resolution encouraging "citizens to take responsibility for their own health" (Gale 2011). Missing from such approaches are less individualistic factors in consumption like advertising, availability, and responses to structural violence.

Other countries like Fiji and Tonga sought to ban importation of mutton flaps. Fiji imposed its ban in 2000; Tonga's effort encountered firm resistance from New Zealand at Commonwealth Health Ministers meetings. Ultimately, Tonga gave up on the idea of restricting mutton flaps as it sought and ultimately achieved entry into the World Trade Organization, which opposes such item-specific import bans (Gale 2011).

In Ghana in 1999, the Ministry of Trade and Industry also moved to ban turkey tails and other poultry products with a fat content that exceeded $15 \%$ because of health factors. Subsequently the Ministry of Food and Agriculture ceased issuing permits for the importation of turkey tails into the country. Despite these actions, it soon became clear that turkey tails were still available and being sold by vendors and retail outlets, suggesting that legal importation had given way to smuggling (Berkout 2010). In response, the Food and Drug Board issued a warming to smugglers and sellers, and asked the public to provide information on anyone they knew who was involved in illegal importation of turkey tails. Subsequently the Board initiated a number of seizures and the destruction of turkey tail contraband.

In 2013, Samoa formally lifted its ban on the importation of turkey tails as part of its accession to the World Trade Organization, re-opening the trade route that could bring the byproduct back into the country. However, Samoa implemented, with World Trade Organization approval, a temporary duty on imported turkey tails while embarking on a public education program. Popular response in Samoa to this shift was mixed, with some people happily anticipating the return of turkey tails and others questioning why the government would put trade and the demands of wealthy nations over the health of the nation's people (Malifa 2013).

\section{Conclusion}

Political ecology "demonstrates consumption's interrelationships with other social, cultural, [economic], and geographic changes as well as changes in the biophysical environment" (Heyman 2004:123). At the local level, in the case of turkey tales, these changes are seen in expanding patterns of purchase of imported foods in retail outlets and ready-made street foods, the incorporation of food produced in distant lands under unfamiliar conditions into a cultural meaningful cuisine, and in shrinking patterns of producing and consuming locally grown foods. Beyond the local level, as Heyman (2004:121) also argues, "Modern consumption does not arrive alone. It requires new sources of income and credit and travels along novel paths of trade and commerce." In the modern world, these innovations are pushed by efforts to take advantage of available technologies for the production and movement of commodities and profits globally. 
Ultimately, the political ecology of consumption, "rests on understanding the importance of unequal power in our social and natural lives" (Heyman 2004:128). Thus, Gerwetz and Errington (2010:2) comment with reference to cheap foodstuffs exported to low-income countries that "the foods on our plates are often obtained at the expense of foods not on other people's plates." Food and its distribution are reflections of broad structures of political economic and political-ecological relationships that now span the globe (Leatherman and Goodman 2005). In our globalized world, "[c]ontrol of a food system is an instrument of dominion" (Hughes and Lawrence 2005:300). It is, in the view of Hughes and Lawrence (2005:300) a "new colonialism," involving the use of policies and practices by wealthy nations in their dealings with poorer nations, actions that have direct and telling consequences for people's health and survival. As this suggests, contrary to the neoliberal assertion that the free flow of commodities is of general benefit in a time of greater closeness among nations, in a world of distinctly richer and poorer lands and peoples, and a vastly unequal distribution of power, trade is not a neutral economic process, but is itself, on the one hand, a tool in the arsenal of power, and on the other, a force in the rise of health problems in countries that now suffer the double burden of infectious and chronic diseases (Lang and Heasman 2004). To paraphrase Egger and Swinburn (1998), growing patterns of obesity in places like the Pacific should be understood as normal physiology within a pathological political ecology involving intertwined micro-environmental (e.g., diminished inclusion of traditional locally grown vegetables in the diet) and macro-environmental (factory farming, globalized distribution) factors.

While packaging, transportation, and preservation are calculated by producers and traders into the cost of exporting "killer commodities"—goods that result in a notable burden of injuries and death (Singer and Baer 2008) - health impacts on consumers are not. Because of the emergence of a corporate culture that, despite numerous assertions to the contrary, puts corporate profits far above customer well-being and pushes companies to fight like pit bulls against government regulation, the failure of governments to protect their publics from harmful corporate products, and even consumer participation under structurally challenging conditions in the purchases of items known to be dangerous or unhealthy, killer commodities take a steep toll on human life and well-being. Under neoliberalism, ultimately, only consumers are seen as responsible, irrespective of economic and cultural factors that shape social behaviors within narrow ranges of possibility made possible by structural factors like the global economy, government policy, and mechanisms of inequality. As Boyd Swinburn comments "If the meat exporters had to pay for part of the diabetes costs they might think twice about [their trade in fatty meats]" (Seccombe 2012).

\section{References}

Apparduai, A. 1986. Introduction: commodities and the politics of value. In A. Appadurai (ed.) The social life of things: commodities in cultural perspective. Cambridge: Cambridge University Press. Pp 3-62.

Baer, H. and Singer, M. 2009 Global warming and the political ecology of health: emerging crises and systemic solutions. Walnut Creek, CA: Left Coast Press.

Barclay, E. 2013. Samoans await the return of the tasty turkey tail. NPR Foodways. May 9.

Bautista, L. 2010. Steadfast movement around Micronesia: Satowan enlargements beyond migration. Lanham, MD: Lexington Books.

Benson, P. 2012. Tobacco capitalism: growers, migrant workers, and the changing face of a global industry. Princeton, NJ: Princeton University Press.

Berkhout, N. 2010. Ban of turkey tails in Ghana. World Poultry. Feb. 15.

Biritwum, R., Gyapong, J. and G. Mensah, G. 2005. The epidemiology of obesity in Ghana. Ghana Medical Journal 39(3):82-85.

Brownell, K. and Yach, D. 2006. Lessons from a small country about the global obesity crisis. Global Health 2:11.

Cassels, S. 2006. Overweight in the Pacific: links between foreign dependence, global food trade, and obesity in the Federated States of Micronesia. Globalization and Health 2:10.

Crawford, D., J. Robert and K. Ball (eds.). 2010. Obesity epidemiology: from aetiology to public health. Oxford: Oxford University Press. 
Curtis M. 2004. The obesity epidemic in the Pacific Islands. Journal of Development and Social Transformations 1: 37-41.

Dadzie, A. 2010. Don't touch my Chofi. Atokd.com, April.

Dallman, M., Pecoraro, N. and S. La Fleur. 2005. Chronic stress and comfort foods: self-medication and abdominal obesity. Brain, Behavior, and Immunity 19 (4): 275-280.

Daykin, T. 2001. Hormel gobbles up turkey store for \$334 million. Milwaukee Journal Sentinel 01D.

Dollar, D. 2001. Is globalization good for your health? WHO Bulletin 79(9): 827-833.

Egger, G. and Swinburn, B. 1997. An "ecological" approach to the obesity pandemic. British Medical Journal 315(7106): 477-480.

Englberger, L., Marks, G. and M. Fitzgerald. 2002. Insights on food and nutrition in the Federated States of Micronesia: a review of the literature. Public Health Nutrition 6(1): 5-17.

Feachem, R. 2001. Globalisation is good for your health, mostly. British Medical Journal 323: 504-506.

Food and Agricultural Organization. 2003. Trade reforms and food security: conceptualizing the linkages. Rome: FAO.

Foster, R. 2006. Tracking globalization: commodities and value in motion. In C. Tilley, W. Keane, S. Kuechler-Fogden, and M. Rowlands (eds.). The handbook of material culture. London: Sage. Pp. 285302.

Franklin, B. 1907 (original 1784) Franklin's letter to his daughter Mrs. Sarah Bache. In A. Smyth (ed.). The Writings of Benjamin Franklin. New York: The Macmillan Co.

Gale, J. 2011 Choosing between free trade and public health. Bloomberg Business Week. Nov. 22.

Gewertz, D. and Errington, F. 2007. The alimentary forms of the global life: the Pacific Island trade in lamb and mutton flaps. American Anthropologist 109(3):496-508.

Gewertz, D. and Errington, F. 2010. Cheap meat: flap food nations in the Pacific Islands. Berkeley: University of California Press. review

Hall, K. 2012. Pardoned turkey peace dies just before Thanksgiving. Huffington Post. Nov. 11.

Hart, J. 2003. The changing scale of American agriculture. Charlottesville: University of Virginia Press.

Haugerud, A., Stone, M. and P. Little. 2010 Commodities and globalization: anthropological perspectives. Lanham, MD: Rowman and Littlefield.

Hawkes, C. 2006. Uneven dietary development: linking the policies and processes of globalization with the nutrition transition, obesity and diet-related chronic diseases. Globalization and Health 2:4.

Hawkes, C., Blouin, C., Drager N. and Dubé, L. (eds.) 2010. Trade, food, diet and health: perspectives and policy options. Malden, MA: Wiley-Blackwell.

Heyman, J. 2004. The political ecology of consumption: beyond greed and guilt. In Paulson, S. and Gezon, L.L. (eds.) Political ecology across spaces, scales and social groups. Brunswick, NJ: Rutgers University Press. Pp 113-134.

Hughes, R. and Mark, L. 2005 Globalisation, food and health in Pacific Island countries. Asian Pacific Journal of Clinical Nutrition 14(4): 298-306.

Ichiho, H., Faiese, R., Ponausuia, E. and N. Aitaoto. 2013a. An assessment of non-communicable diseases, diabetes, and related risk factors in the Territory of American Samoa: a systems perspective. Hawai'i Journal of Medicine and Public Health 72(5, Supplement 1):10-18.

Ichiho, H., Yorah, D., Stevenson, K. and N. Aitaoto. 2013b. An assessment of non-communicable diseases, diabetes, and related risk factors in the Republic of Palau: a systems perspective. Hawai'i Journal of Medicine and Public Health 72(5, Supplement 1):98-105.

Ichiho, H., deBrum, I., Kedi, S., Langidrik, J. and N. Aitaoto. 2013c. An assessment of non-communicable diseases, diabetes, and related risk factors in the Republic of the Marshall Islands, Majuro Atoll: a systems perspective. Hawai'i Journal of Medicine and Public Health 75(5, Supplement 1):87-97.

International Economic Law and Policy Blog. 2011. Trade in everything: turkey tails. Nov. 24.

Jackson, R. 1997. Dietary genocide: eating to an early death in Micronesia. Pacific Health Dialog 4(1): 88-89. 
King, B. 2010. Political ecologies of health. Progress in Human Geography 34(2): 38-56.

Kopytoff, I. 1986. The cultural biography of things: commoditization as process. In A. Appadurai (ed.) The social life of things: commodities in cultural perspective. Cambridge: Cambridge University Press. Pp 64-91.

Krispe, G. 2005. Food aid or hidden dumping? Separating wheat from chaff. Oxfam Briefing Paper 71. Oxfam International.

Lang, T. and Heasman, M. 2004. Food wars: the global battle for mouths, minds and markets. London: Earthscan.

Law, F. 2001. Rice industry in crisis, President told. Delta Farm Press. July 20.

Leatherman, T. and Goodman, A. 2005. Coca-colonization of diets in the Yucatan. Social Science and Medicine 61(4): 833-846.

Lubin, G. 2010. Everything you need to know about the big turkey industry. Business Insider. Nov. 25.

Malifa, S. 2013. About the H.R.P.P., "Turkey Tails" and W.T.O. Samoa Observer. April 24.

Marshall, M. 2004. Namoluk beyond the reef: the transformation of a Micronesian community. Boulder, Co: Westview Press.

Marx, K. 1990 (1867). Capital. Volume 1. London: Penguin Classics.

McMichael A. and R. Beaglehole. 2000. The changing global context of public health. The Lancet 356: 495499.

Miller, D. 1995. Consumption and commodities. Annual Review of Anthropology 24:141-161.

Minnesota Turkey. 2014. Turkey - gobble it up. Http://minnesotaturkey.com

Modern Ghana. 2010. FDB asks to reconsider the ban of Tsofi. 18 June.

Munn, S. 2010. Turkey tails and multicoloured rice. Elilai Petals Blog. Feb.

National Agricultural Statistics Service. 2007. Overview of the U.S. turkey industry. Washington, D.C.: NASS.

National Turkey Federation 2012. Annual Report. Washington D.C.: National Turkey Federation.

Ollinger, M., MacDonald, J. and M. Madison. 2000. Structural change in U.S. chicken and turkey. Economic Research: Report No. 787. Washington, D.C: U.S. Department of Agriculture.

Panapasa, S. 2012. Turkey tails contribute to high obesity rates among Pacific Islanders. Youtube video, Nov. 2012.

Phys.org. 2012. A tale of turkey tail: the part of the bird best left uneaten. Nov. 14.

Pingali, P. 2007. Westernization of Asian diets and the transformation of food systems: implications for research and policy. Food Policy 32(3):281-298.

Pope, S. 1997. Patriotic games: sporting traditions in the American imagination, 1876-1926. New York: Oxford University Press.

Popkin, B. 1998. The nutrition transition and its health implications in lower-income countries. Public Health Nutrition 1(1): 5-21.

Radio New Zealand 2007. Samoa government bans import of U.S turkey tail meat. 26 April.

Richburg, K. 2011. U.S., China embroiled in trade spat over chicken feet. The Washington Post. 17 Dec.

Santino, J. 1994 All around the year: holidays and celebrations in American life. Urbana, IL: University of Illinois Press.

Seccombe, M. 2012. Bum deal on back end of big bird. The Global Mail Nov. 19.

Shell, E. 2001 New world syndrome: spam and turkey tails have turned Micronesians into Macronesians. A case study of how fatty western plenty is taking a disastrous toll on people in developing countries. The Atlantic Monthly 287(6): 50-53.

Shishkin, P. and D. Crawford. 2006. In Afghanistan, heroin trade soars despite U.S. aid. Wall Street Journal January 18: 1.

Singer, M. and H. Baer (eds.) 2008. Killer commodities: public health and the corporate production of harm. Malden, MA: AltaMira/Roman Littlefield Publishers. 
Singer, M. and Erickson, P. 2013. Global health: an anthropological perspective. Long Grove, Illinois: Waveland Press.

Siskin, J. 1992. The invention of Thanksgiving: a ritual of American nationality. Critique of Anthropology 12:167-191.

Straw, W. 1998. The thingishness of things. Keynote address for the Interrogating Subcultures Conference, University of Rochester, March 27.

Sub-Regional Workshop on Trade, Trade Agreements and Non-Communicable Diseases. 2013. Trade, trade agreements and noncommunicable diseases of the Pacific Islands: intersections, lessons learned, challenges and way forward. Suva: UNDP.

The Meat Site. 2013. Global poultry trends: more turkey meat eaten but less per person.

Thow, A., Heywood, P., Schultz, J., Quested, C., Jan, S. and S. Colagiuri. 2011. Trade and the nutrition transition: strengthening policy for health in the Pacific. Ecology of Food and Nutrition 50:18-42.

Ulukalala Lavaka 'Ata. 2002. Press Conference, Nuku'alofa, Kingdom of Tonga, February 14.

U.S. Department of Agriculture. 1995 How to buy poultry. Home and Garden Bulletin 263.

U.S. Department of Agriculture. 2008. Poultry market statistics, 2008. Summary.

USA Poultry and Egg Export Council. 2009. Expired chicken meat is being imported to Ukraine.

USA Poultry and Egg Export Council. 2013. Kazakhstan poultry producers are on the verge of bankruptcy.

Waters, M. 2005. Globalization. London: Routledge.

Whatmore, S. and Thorne, L. 1997. Nourishing networks: alternative geographies of food. In D. Goodman and M.J. Watts (eds.). Globalising food: agrarian questions and global restructuring. New York: Routledge. Pp. 287-304.

World Health Organization. 2004. Organization preventing chronic disease: a vital investment. Geneva: WHO.

Wyber, R., Wilson, N. and M. Baker. 2009. New Zealand's impact on health in the South Pacific: scope for improvement? The New Zealand Medical Journal 122(1291): 60-68. 